\title{
Impact of climate change and anthropogenic interventions on natural vis-à- vis human resources in Kashmir, India - An overview
}

\author{
Peerzada Ishtiyak ${ }^{1 *},{ }^{2}$ Mohan Reddy ${ }^{2}$, Shiv Panse, Irfan Wani ${ }^{3}$ and Quadri Javeed Ahmad \\ Peer $^{4}$ \\ ${ }^{1}$ Faculty of Forestry, Sher-e-Kashmir University of Agricultural Sciences \& Technology (SKUAST) Kashmir \\ (J\&K) INDIA \\ ${ }^{2}$ Temperate Institute of Sustainable Innovations, New Delhi, INDIA \\ ${ }^{3}$ DFO, J\&K Forest Department. Bandipora, Kashmir, INDIA \\ ${ }^{4}$ Faculty of Agriculture, Sher-e-Kashmir University of Agricultural Sciences \& Technology (SKUAST) Kashmir \\ (J\&K) INDIA \\ *Corresponding author. E-mail: drishtiyak@gmail.com
}

Received: May 4, 2015; Revised received: December 4, 2015; Accepted: February 2, 2016

\begin{abstract}
Climate change is one of the biggest challenges the world is facing today and it has the potential to create havoc with the agrarian livelihoods across the globe. Therefore, this paper attempts to explain the probable impacts of human induced climate change on natural resources in Kashmir, India. An ample amount of literature was reviewed meticulously to ascertain the impacts of climatic variability on natural resources vis-a-vis agriculture, biodiversity and water bodies as well as other common issues related to human resources in Kashmir. Loss of certain indigenous food varieties (i.e. nick cheena), reduction in natural forest cover (less than 11\%) and loss of important water resources has aggravated the already dilapidated situation in this most vulnerable state of India. Scientific evidences revealed that there will be more devastating climatic effects on natural resources in Kashmir- India, which will fall disproportionately on poor communities, particularly dry land farmers, forest dwellers and fishermen of the state.
\end{abstract}

Keywords: Anthropogenic pressures, Climate change, Kashmir, Natural resources

\section{INTRODUCTION}

Climate has been the most determinable factor for livelihood patterns on the earth. It is now a universally accepted phenomenon that, climate change is one of the principal environmental problems of present times (IPCC, 2014). It is also important to note that the climate change is not only a major global environmental problem, but also an issue of great concern at local level, especially within developing countries like India (Gerlitz, 2015).

Jammu \& Kashmir (J\&K) State constitutes the northern most extremity of India, situated between $32^{\circ} 17^{\prime}$ to $37^{\circ} 05^{\prime}$ North latitude and $72^{\circ} 31^{\prime}$ to $80^{\circ} 20^{\prime}$ East longitude. The total geographical area of the state is 22 , $22,236 \mathrm{~km}^{2}$ (FSI, 2011). The annual rainfall varies from region to region with $92.6 \mathrm{~mm}$ in Srinagar and $1115.9 \mathrm{~mm}$ in Jammu. The impact of climate change in $\mathrm{J} \& \mathrm{~K}$ is clearly noticeable in terms of erratic rainfall \& snowfall, snow tsunamis, floods, rising temperatures, loss of glaciers, water bodies and depletion of biological diversity. Increasing anthropogenic stresses are further aggravating this situation and the day to day human affairs which are already affected in numerous ways are provoked by the changing climate.

The far reaching ill effects of climate change on the temperate regions are of high magnitude. The third assessment report (TAR, 2001) of the Inter - Governmental Panel on Climate Change - analysis of the temperature trend in the Himalayas and its vicinity shows that, temperature variation are greater in the uplands than lowlands. Shrinkage of glaciers, thawing of permafrost, late freezing and earlier break up of ice on rivers and lakes, pole-wards and altitudinal shifts of plant and animal species, declines of some plant and animal populations, and earlier emergence of insects have been observed (IPCC, 2007). Climate of the Jammu \& Kashmir state differs from region to region based on the variations in its altitude ranging from 305 metres to 6910 metres above sea level. This state in general and Kashmir valley in particular has witnessed an immense variability and shift in the temperatures (Table 1). The climate of the Jammu \& Kashmir is greatly influenced by tropical heat of Punjab, arctic cold of Ladakh and the presence of mountains like Pir-panjal, Zanaskar and Karakoram which check the moisture-laden winds from entering the Kashmir valleys. There is no effect of South- west monsoon in Kashmir valley and the 
precipitation mainly occurs during western disturbances. The precipitation pattern in the Kashmir indicated a significant deviation due to the climate change. The average rain fall and rainy days in the Kashmir increased abruptly. However, the rain fall in the majority of the weather station reported a decreasing trend. The data on annual rainfall for Kashmir from 1980 to 2008 is given in table 2 .

Projection of climate variability for Kashmir: The projection of climate variability for Jammu and Kashmir is predicted by The Indian Network for Climate Change Assessment (INCCA) in 2010. The assessment period of the study is from 2021-2050 under SRES scenario A1B (atmospheric $\mathrm{CO}_{2}$ concentration of 490 ppm by 2035). This model has predicted an increase in minimum temperature from $1{ }^{\circ} \mathrm{C}$ to $4.5^{\circ} \mathrm{C}$ and the maximum temperature may rise by $0.5^{\circ} \mathrm{C}$ to $2.5^{\circ} \mathrm{C}$. The model has also predicted an extreme shift in precipitation pattern with an average increase of 5 to 10 rainy days in Jammu \& Kashmir region by 2030 . The intensity of rainfall is likely to increase by $1-2 \mathrm{~mm} /$ day particularly in the eastern part of the Jammu and Kashmir (Das et al., 2014).

Impact of climatic variability on natural resources of Kashmir: It is well established fact that the climate variability has a great influence on human and natural resources. The climate change impact may remain only for few hours or may last through years and shows greater effect on primary sectors like bio-resources, agriculture and allied sectors. In the Kashmir region the impact of climate change will be more negative, aggravating economic and social problems.

Agriculture: Agricultural sector is extremely sensitive to climate variability and weather extremes, such as droughts, hail storms, wind storms and early frosts. The parameters that form our climate are also significant to farm productivity; the increased potential of droughts, floods and heat waves will pose challenges for farmers (Kumar and Gautam, 2014). In addition, the continuing changes in climate, water supply and soil moisture could make it less feasible to continue crop production in certain areas. Climate variability and change also increases the risks of fires, pest and pathogen outbreak, negatively affecting food, fiber and forestry (IPCC, 2007). As reported by Chand and Kumar (2011) about 130 million hectare land is undergoing different levels of degradation, namely water erosion (32.8 mha), wind erosion (10.8 mha), salinization (7.0 mha.), desertification (68.1 mha), water logging (8.5 mha) and nutrient depletion (3.2 mha) etc. this has serious impact on the decreasing food productivity, attack of insect and pest on crops, early or late maturity of crops etc. Kashmir is one of the unique and most fragile temperate ecosystem in Himalayan region, where livelihood of people is heavily dependent on natural resources and environment. About $70 \%$ of the State Gross Domestic Product (SGDP) is drawn from the surrounding eco- logical resources and more than $75 \%$ population of the valley is dependent on agriculture, horticulture, forests and handicrafts. Due to certain environmental changes like rising temperatures, erratic rains and snowfall and fast receding glaciers, water is becoming scarcer and availability of water has become a significant problem. A study conducted by a non-government organization (Talib, 2007) reported that the shortage in food production in Kashmir region has reached $40 \%$, while the deficit is $30 \%$ in vegetable production and $69 \%$ in oilseed production for a population of 6 million, putting food security at a greater risk. In 1980- 81, Kashmir valley had a food deficit of only $23 \%$ for a total population of 3.3 million. As more and more paddy land is changed into rain-fed orchards, Kashmir's current $40 \%$ food grain deficit is likely to touch over 60 $\%$ in the coming decade if the current rate of change is taken into account. It also reports that 11909 Kanals of paddy land have been converted into rain-fed dry land in the districts of Anantnag, Baramulla, Bandipora, Badgam, Pulwama, Kulgam and Shopian (Table 3) in recent years because of erratic rainfall.

The report further states that, due to general increase in temperature and less availability of water, summer varieties of rice like nick cheena and traditional Kashmiri apples have almost disappeared from the area. Over the last few years there has been distinct slow growth in production of fruits in Kashmir, some factors of which can be attributed to climate change (Basannagari and Kala, 2013).

Biodiversity: The inflexibility of many ecosystems is likely to exceed in future by an unprecedented combination of climate change and associated disturbances like drought, wildfire, floods, infestation of insects; and other global change drivers viz., land use change, pollution, and overexploitation of natural resources particularly forests. Scientists have reported that approximately 20-30\% of plant and animal species assessed so far are likely to be at increased risk of extinction if increase in global average temperature exceeds $1.5^{\circ} \mathrm{C}$ to $2.5^{\circ} \mathrm{C}$ (Chand and Kumar, 2011). The $\mathrm{J} \& \mathrm{~K}$ State has rich biodiversity and is considered to be bestowed with rare species of flora and fauna. The flora ranges from the thorn bush type of the arid plain to the temperate and alpine flora of the higher altitudes including broad leaf trees species like maple, horse chest nuts etc. Forests are the fundamental resources for the economic and livelihood activities in the state of J\&K. Majority of the State's population is heavily dependent on forests to meet their household demands including firewood, fodder, food, medicinal plants and other non-timber forest products. However, commercial extraction of timber from the forests in the past, coupled with excessive grazing, encroachments, illicit felling of trees, and diversion of forest land for non-forestry purposes has resulted in degradation of forests. The recorded forest area of the state is 20, $2030 \mathrm{~km}^{2}$. Reserved forests constitute $87.21 \%$, pro- 
Table 1. Mean of the maximum and minimum temperature (in ${ }^{\circ} \mathrm{C}$ ) of Kashmir during 1985 to 2007.

\begin{tabular}{|c|c|c|c|c|c|c|c|c|c|c|c|c|c|c|c|}
\hline \multirow[b]{2}{*}{ Months } & \multicolumn{15}{|c|}{ Year } \\
\hline & 1985 & 1990 & 1995 & 1996 & 1997 & 1998 & 1999 & 2000 & 2001 & 2002 & 2003 & 2004 & 2005 & 2006 & 2007 \\
\hline January & 6.4 & 8.9 & 3.2 & 5.9 & 3.2 & 5.9 & 7.6 & 11.7 & 9.3 & 11.2 & 7.1 & 7.5 & 4.3 & 10.0 & 05.5 \\
\hline February & 13.0 & 9.8 & 6.8 & 10.7 & 10.8 & 10.7 & 10.2 & 13.7 & 9.5 & 10.3 & 13.0 & 6.5 & 13.4 & 12.0 & 08.7 \\
\hline March & 18.3 & 12.6 & 13.6 & 14.1 & 14.2 & 15.5 & 15.2 & 18.0 & 16.8 & 13.7 & 21.7 & 14.7 & 16.0 & 14.7 & 20.0 \\
\hline April & 21.1 & 18.9 & 17.6 & 19.9 & 19.4 & 24.7 & 23.1 & 21.7 & 20.6 & 21.0 & 20.7 & 20.7 & 21.1 & 25.6 & 20.1 \\
\hline May & 24.0 & 28.1 & 25.1 & 21.3 & 22.5 & 26.0 & 29.1 & 28.4 & 26.5 & 22.2 & 25.4 & 21.8 & 28.2 & 25.5 & 25.6 \\
\hline June & 29.4 & 30.2 & 30.5 & 26.9 & 27.4 & 30.3 & 30.1 & 29.6 & 28.9 & 30.1 & 27.8 & 29.3 & 27.6 & 27.8 & 29.6 \\
\hline July & 30.0 & 30.8 & 29.8 & 29.4 & 31.9 & 31.6 & 30.0 & 30.1 & 30.5 & 30.9 & 29.4 & 28.9 & 30.9 & 29.8 & 29.9 \\
\hline August & 30.0 & 29.0 & 28.7 & 27.5 & 29.1 & 29.9 & 29.6 & 30.2 & 29.8 & 28.6 & 29.3 & 30.4 & 28.7 & 30.1 & 29.5 \\
\hline September & 29.0 & 28.1 & 26.9 & 28.4 & 27.8 & 29.7 & 27.1 & 26.9 & 25.1 & 26.9 & 29.0 & 29.3 & 25.9 & 27.3 & 26.5 \\
\hline October & 21.0 & 22.5 & 21.10 & 19.8 & 19.9 & 24.7 & 25.6 & 24.4 & 23.3 & 23.0 & 20.6 & 22.7 & 22.9 & 24.1 & 22.9 \\
\hline November & 16.0 & 16.8 & 15.8 & 13.1 & 13.7 & 15.4 & 17.2 & 15.5 & 18.5 & 15.4 & 17.9 & 15.8 & 15.0 & 17.1 & 15.4 \\
\hline December & 9.0 & 7.3 & 6.2 & 7.7 & 8.4 & 12.6 & 11.0 & 10.6 & 10.0 & 10.0 & 9.7 & 09.9 & 08.4 & 9.9 & 10.4 \\
\hline
\end{tabular}

Source: Regional Meteorological Centre, Srinagar \& Jammu.

Table 2.Average rainfall and rainy days in Kashmir during 1980 to 2008 (in mm).

\begin{tabular}{|c|c|c|c|c|c|c|c|c|c|c|c|c|c|c|}
\hline Years & 1980 & & 1985 & & 1990 & & 1995 & & 2000 & & 2005 & & 2008 & \\
\hline IMD & Rainy & Rain & Rainy & Rain & Rainy & Rain & Rainy & Rain & Rainy & Rain & Rainy & Rain & Rainy & Rain \\
\hline Stations & Days & Fall & Days & Fall & Days & Fall & Days & Fall & Days & Fall & Days & Fall & Days & Fall \\
\hline Srinagar & NR & NR & NR & NR & 57 & 937.4 & 65 & 814.9 & 52 & 399 & 72 & 680 & 85 & 649 \\
\hline Pahalgam & NR & NR & NR & NR & 86 & 1357.1 & 99 & 1438.7 & 88 & 913 & 132 & 1300 & 120 & 1038 \\
\hline Kukernag & NR & NR & NR & NR & 47 & 732.5 & 77 & 1256.0 & 55 & 513 & 107 & 1107 & 108 & 1215 \\
\hline Qazigund & NR & NR & NR & NR & 67 & 1075.0 & 80 & 1508.3 & 63 & 816 & 109 & 1275 & 102 & 1075 \\
\hline Handwara & 54 & 580.8 & NR & NR & 55 & 664.7 & 85 & 1015.9 & - & - & - & - & - & - \\
\hline Gulmarg & NR & NR & NR & NR & 91 & 1852.3 & 108 & 974.4 & 1 & 1064 & 140 & 1663 & 125 & 1222 \\
\hline Kupwara & NR & NR & NR & NR & NR & NR & NR & NR & 61 & 573 & 106 & 970 & 108 & 989 \\
\hline
\end{tabular}

IMD - Indian Metrological Department, NR - Not Reported. Source: Regional Meteorological Centre, Srinagar \& Jammu.

Table 3. Paddy land being changed into rain-fed horticulture land in some districts of Kashmir (Figures given in table are approximate).

\begin{tabular}{llll}
\hline S. $\mathbf{~}$. & District & Total area $\mathbf{~ k m}^{2}$ & Land changed (in kanals*) \\
\hline 1 & Anantnag & 3,984 & 3700 \\
2 & Bandipora & 398 & 695 \\
3 & Baramulla & 4,588 & 1152 \\
4 & Budgam & 1,371 & 1112 \\
5 & Kulgam & & 1250 \\
6 & Pulwama & 1,398 & 2500 \\
7 & Shopian & 1500 \\
$*$ A kanal is a traditional unit of land area, equivalent to $505.857 \mathrm{~m}^{2}$ or 0.125 acres. \\
\hline
\end{tabular}

Source: A report on climate change and its impact in Kashmir (Talib, 2007).

Table 4. District-wise forest cover of $J \& K$ state (area in $\mathrm{km}^{2}$ and change matrix).

\begin{tabular}{|c|c|c|c|c|c|c|c|c|}
\hline \multirow[t]{2}{*}{ District } & \multirow{2}{*}{$\begin{array}{l}\text { Geographical } \\
\text { Area (GA) }\end{array}$} & \multicolumn{4}{|c|}{2011 Assessment } & \multirow{2}{*}{$\begin{array}{l}\text { Percent } \\
\text { of GA }\end{array}$} & \multirow[t]{2}{*}{ Change* } & \multirow[t]{2}{*}{ Scrub } \\
\hline & & $\begin{array}{l}\text { Very Dense } \\
\text { Forest }\end{array}$ & $\begin{array}{l}\text { Moderately } \\
\text { Dense Forest }\end{array}$ & Open Forest & Total & & & \\
\hline Anantnag & 3984 & 196 & 664 & 578 & 1438 & 36.09 & 0 & 23 \\
\hline Baramulla & 4588 & 425 & 286 & 446 & 1157 & 25.22 & 0 & 86 \\
\hline Budgam & 1371 & 99 & 69 & 52 & 220 & 16.05 & 0 & 8 \\
\hline Doda & 11691 & 619 & 1689 & 1659 & 3967 & 33.93 & 0 & 5 \\
\hline Jammu & 3097 & 0 & 210 & 672 & 882 & 28.48 & 0 & 43 \\
\hline Kargil & 14037 & 0 & 3 & 21 & 24 & 0.17 & 0 & 19 \\
\hline Kathua & 2651 & 112 & 672 & 614 & 1399 & 52.77 & 1 & 12 \\
\hline Kupwara & 2379 & 472 & 366 & 322 & 1160 & 48.76 & 0 & 3 \\
\hline Leh & 45110 & 0 & 48 & 57 & 105 & 0.23 & 0 & 6 \\
\hline Outside LOC & 120848 & 1326 & 2471 & 2686 & 6483 & 5.36 & 1 & 1810 \\
\hline Poonch & 1674 & 187 & 300 & 242 & 729 & 43.55 & 0 & 9 \\
\hline Pulwama & 1398 & 110 & 106 & 78 & 294 & 21.03 & 0 & 10 \\
\hline Rajouri & 2630 & 49 & 239 & 752 & 1240 & 47.15 & 0 & 8 \\
\hline Srinagar & 2228 & 196 & 307 & 249 & 752 & 33.75 & 0 & 16 \\
\hline Udhampur & 4550 & 349 & 1129 & 1211 & 2689 & 59.10 & 0 & 47 \\
\hline Grand Total & 222,236 & 4140 & 8760 & 9639 & 22539 & 10.14 & 2 & 2105 \\
\hline
\end{tabular}

Source: Indian State of Forest Report (FSI, 2011). 
tected forests $12.61 \%$ and unclassed Forests $0.18 \%$ of the total forest area. The protected area network of the J\&K state is spread over 4 National Parks, 15 Wildlife Sanctuaries and 33 Conservation Reserves covering an area of $14,997.86 \mathrm{~km}^{2}$ which constitutes $6.75 \%$ of the State's geographic area (FSI, 2011). About fifty years ago forest cover of Kashmir was $37 \%$ of its total surface area (Talib, 2007), which has today reduced to less than $11 \%$ as reported by FSI, 2011 (Table 4).

Water resources: The global hydrological cycle can have major impacts on regional water resources, affecting both ground and surface water supply for domestic and industrial uses, irrigation, hydropower generation, navigation, in-stream ecosystems and waterbased recreation. Increase in surface temperature warms the climate, which in-turn may lead to intensification of the hydrological cycle, resulting in higher rates of evaporation and increase of liquid precipitation. On regional scales, mountain snow, glaciers, and small ice caps play a crucial role in freshwater availability. However, widespread mass losses from glaciers due to climate change have resulted in glacier advance, retreat, reduction in snow cover and landslide threat over the recent years. If such situation continues it will reduce the water availability and hydropower potential, and changing seasonality of flows. Talib (2007) reported that reduction of the Himalayan glaciers, could endanger water supplies for hundreds of millions of people. A study of 466 Himalayan glaciers by scientists with the Indian Space Research Organisation (ISRO) has estimated that most of the glaciers in the Kashmir valley have disappeared and rest have decreased in size. In areas like Budgam, the height (averaging 15-20 feet) of a small glacier has been reduced to one-fourth of the original size (Talib, 2007).

\section{Common issues related to climate change}

Health: It is established that the changing climate will bring much more frequent and extreme weather events in future, which have the potential to influence human health in several direct and indirect ways. Due to its severe impacts on population the climate change is considered as the biggest potential threat to the human health (Hales and Woodward, 2006; Costello et al., 2009 ) in $21^{\text {st }}$ century. Rising temperatures will lead to increased heat-related deaths, illnesses and pest and disease vectors, risk of infectious disease epidemics etc. Increased rainfall variability is likely to increase food-borne and water-borne diseases (Crump et al., 2001). Climate change is believed to pose threat to human behaviour (Fuquay, 1989). Indian Metrological Department (IMD) monitoring reveals that temperatures are escalating in both regions of Jammu and Kashmir with significant increase in maximum temperature by $0.05^{\circ} \mathrm{C}$ per year in Kashmir valley and minimum temperature in Jammu by $0.08^{\circ} \mathrm{C}$ per year. For instance the month of May in 2007 has unusual cold in Kashmir. The temperature lowered around $25^{\circ}$ to $26^{\circ} \mathrm{C}$ during the second fortnight of May which according to experts is $8^{\circ} \mathrm{C}$ below normal.

Disasters: There is hardly any region left in the world where natural or manmade disasters have not caused havoc especially during the last few decades. It is estimated that around 250 million people are affected every year due to natural disasters, in which about $98 \%$ are due to climate-related hazards, predominantly floods and windstorms, followed by droughts. During the period 1987-2006, the number of reported disasters related to hydro-metrological hazards (droughts, floods, tropical storms, wild fires) showed a significant increase: from an average of 195 per year in 1987-1998 to 365 per year in 2000-2006 (FAO, 2003). The international aid agencies have spent around $\$ 2.7$ billion (1.9 billion Euros) since 1992 (FAO, 2008) for the relief measures in Kashmir valley. Both the capital cities of the state i.e. Jammu and Srinagar are in Seismic zone IV and V respectively. The State has suffered a lot on account of both life and property in the past. Snowstorm in February 2005, earthquake October 2005, heavy snow fall in 2006 (heaviest in three decades), Leh (Ladakh) flash floods in August 2010, and flood in whole Kashmir valley during September 2014, have caused huge loss of human lives, livestock and property.

Political turmoil: Environmental pollution, loss of biodiversity, deforestation, desertification, depletion of water table and water level; in addition to climate change are having deep effects on several societies. Deterioration of the physical environment is a major threat to human security. Military activity affects the physical environment in several direct ways including pollution of the air, land and water. Training grounds and weapons /ammunition depots, when improperly handled or stored, can seep into the environment and affect nearby communities. The incident of weapon depot fire and blasts in an army camp near Anantanag in Kashmir is still afresh in the minds of local inhabitants (Reuters, 2007). The hundreds of heavy military vehicles in over three hundred convoys and other paramilitary and government vehicles move throughout Kashmir every day, producing a high level green house gases (Talib, 2007).

\section{Conclusion}

An analysis of a data on climatic parameters like temperature and rainfall indicated that there has been a major shift of sunny and rainy days in Kashmir valley. The impact on climatic variability is clearly visible in terms of extinction of indigenous species including food crops and loss of water bodies. Appropriate measures coupled with stringent laws need to be put in place immediately. Developing and strengthening activities for public awareness, education and access to information can also prove very beneficial in achieving the sustainable results. There is also urgent need of suitable institutional mechanism for protection, scientific management, conservation and development of 
the available natural resources in the state. The most effective way to address climate change is to adopt a sustainable development pathway, besides using renewable energy, forest and water conservation, etc.

\section{REFERENCES}

Basannagari, B., and Kala, C.P. (2013). Climate Change and Apple Farming in Indian Himalayas: A Study of Local Perceptions and Responses. Convertino M, ed. PLoS ONE, 8(10).

Chand, S. and Kumar, R. (2011). Challenges of Climate Change Vis-A-Vis Tactic for Cooling the Earth. Universal Journal of Environmental Research and Technology, 1(2): 222-226.

Costello, A., Abbas, M. and Allen, A. (2009). Managing the health effects of climate change: UCL Institute for Global Health and Lancet Commission. The Lancet, 373: 1693-1733.

Crump, J.A., Murdoch, D.R. and Baker, M.G. (2001). Emerging infectious diseases in an island ecosystem: the New Zealand perspective. Emerging Infectious Diseases, 7(5): 767-772.

Das, P.K., Chakraborty, A. and Seshasai, M.V.R. (2014). Spatial analysis of temporal trend of rainfall and rainy days during the Indian Summer Monsoon season using daily gridded $\left(0.5^{\circ} \times 0.5^{\circ}\right)$ rainfall data for the period of 1971-2005. Met. Apps, 21: 481-493. doi: 10.1002/ met. 1361

FAO. (2003). World agriculture: towards 2015/2030 - An FAO Perspective, Bruinsma (ed.). FAO, Rome and Earthscan. London.

FAO. (2008). Climate Change and Disaster Risk Management - Technical background document -From the expert consultation held on 28 TO 29 February, 2008. FAO, Rome.

Fuquay, J.W. (1989). Heat stress as it affects animal produc- tion. J. Animal Sci. 52, 164-174.

FSI (2011). India State of Forest Report, Forest Survey of India, Dehradun.

Gerlitz, S.B. (2015). An Approach to Measure Vulnerability and Adaptation to Climate Change in the Hindu Kush Himalayas. In W. L. Filho, Handbook of Climate Change Adaptation (pp. 151-176). Berlin: Springer Berlin Heidelberg.

Hales, S. and Woodward, A. (2006). Potential health impacts and policy responses. Confronting climate change: Critical issues for New Zealand.

INCCA. (2010). Climate Change and India:A 4x4 A Sectoral and Regional Analysis for 2030. New Delhi: MoEFCC.

IPCC. (2007). Special Report on Emissions Scenarios. Intergovernmental Panel on Climate Change Secretariat. Geneva, Switzerland. Retrieved on March, 212014 from http://www.grida.no/climate/ipcc/emission/

IPCC. (2014). Climate Change 2014: Synthesis Report. Contribution of Working Groups I, II and III to the Fifth Assessment Report of the Intergovernmental Panel on Climate Change [Core Writing Team, R.K. Pachauri and L.A. Meyer (eds.)]. IPCC, Geneva, Switzerland, $151 \mathrm{pp}$.

Kumar, R. and Gautam, H.R. (2014). Climate Change and its Impact on Agricultural Productivity in India. J Climatol Weather Forecasting, 2: 109.

Reuters. (2007). Three die dozens injured in Kashmir arms depot blaze. Retrieved on March, 23, 2014 from http:// edition.cnn.com/2007/WORLD/asiapcf/08/11/ kashmir.fire.reut

Talib, A.H. (2007). On the brink-A report on Climate Change and its Impact in Kashmir, Action Aid India, Srinagar, Jammu and Kashmir.

TAR. (2001). Climate Change 2001. 'Impacts, Adaptation and Vulnerability'. Third Assessment Report IPCC. Retrieved on November, 182014 from http:// www.ipcc.ch/pub/tar/wg1/ 